KALAMATIKA Jurnal Pendidikan Matematika

Volume 4, No. 1, April 2019, hal. 15-22

$\mathbf{K} \backslash \mathbf{L} \backslash \mathbf{M} / \mathbf{T} \backslash \mathbf{K} /$

\title{
KONTRIBUSI MODEL PEMBELAJARAN M-APOS TERHADAP KEMAMPUAN PEMAHAMAN KONSEP MATEMATIS SISWA
}

\author{
Cahya Dwi Budiarti ${ }^{1}$, Sigid Edy Purwanto ${ }^{2}$, Benny Hendriana ${ }^{3}$ \\ ${ }^{1}$ Universitas Muhammadiyah Prof. DR. HAMKA \\ cayadwi@gmail.com \\ ${ }^{2}$ Universitas Muhammadiyah Prof. DR. HAMKA \\ sigidmath@yahoo.co.id \\ ${ }^{3}$ Universitas Muhammadiyah Prof. DR. HAMKA \\ benny_hendriana@uhamka.ac.id
}

\begin{abstract}
ABSTRAK
Penelitian ini bertujuan untuk mengetahui ada atau tidaknya pengaruh model pembelajaran Modification-Action, Process, Object, Schema (M-APOS) terhadap kemampuan pemahaman konsep matematis siswa. Penelitian ini merupakan penelitian kuantitatif dan menggunakan metode penelitian eksperimen jenis quasi experimental dengan the post-test only design with nonequivalent groups. Sampel yang digunakan sebanyak 73 siswa SMP kelas VII dipilih menggunakan metode cluster random sampling. Instrumen penelitian yang digunakan berupa tes uraian yang valid dan reliabel. Data penelitian berasal dari populasi yang berdistribusi normal namun tidak homogen. Uji hipotesis menggunakan uji-t' pada taraf signifikan 5\% diperoleh $t$ ' sebesar 1,981. Penelitian ini menyimpulkan bahwa terdapat pengaruh model Modification-Action, Process, Object, Schema (M-APOS) terhadap kemampuan pemahaman konsep matematis siswa, dengan kontribusi sebesar 0,411 yang tergolong sedang.
\end{abstract}

Kata Kunci: pemahaman konsep matematis, $M$-APOS, pembelajaran aktif

\begin{abstract}
The aim of this research is to find contribution of M-APOS model to the students' mathematical understanding ability. This study is quantitative research and use quasi experimental with the post-test only design with nonequivalent groups. The sample of this research is 73 students gathered by using cluster random sampling. Instrument used in this research is essay test which valid and reliable. The data are from populations that are normally distributed but not homogeneous. Hypothesis test was using t'-test at significant level of 5\%, obtained t' of 1,981. This study concluded that there is the effect of M-APOS models to the students' mathematical understanding ability, with a contribution of 0,411 which is classified as being moderate.
\end{abstract}

Keywords : M-APOS, mathematical understanding ability, active learning 
Format Sitasi: Budiarti, C.D., Purwanto, S.E., \& Hendriana, B. (2019). Kontribusi Model Pembelajaran M-APOS Terhadap Kemampuan Pemahaman Konsep Matematis Siswa. KALAMATIKA Jurnal Pendidikan Matematika, 4(1), 15-22.

Penyerahan Naskah: 12 Agustus 2018 || Revisi: 26 Maret 2019 || Diterima: 27 Maret 2019

\section{PENDAHULUAN}

Pendidikan memiliki peranan penting dalam menyiapkan sumber daya manusia yang berkualitas dan mampu bersaing, serta memiliki budi pekerti luhur dan moral yang baik. Hal ini sesuai dengan Undang-Undang Republik Indonesia Nomor 20 Tahun 2003 pasal 1 ayat 1 tentang sistem pendidikan nasional yang menyatakan bahwa pendidikan adalah usaha sadar dan terencana untuk mewujudkan suasana belajar dan proses pembelajaran agar peserta didik secara aktif mengembangkan potensi dirinya untuk memiliki kekuatan spiritual keagamaan, pengendalian diri, kepribadian, kecerdasan, akhlak mulia, serta keterampilan yang diperlukan dirinya, masyarakat, bangsa dan negara. Berdasarkan hal tersebut, diperlukan suatu upaya peningkatan kualitas pendidikan. Upaya mendasar yang dapat dilakukan untuk meningkatkan kualitas pendidikan yaitu memperbaiki proses pembelajaran, khususnya pembelajaran matematika.

Matematika sebagai salah satu disiplin ilmu dalam dunia pendidikan memegang peranan penting. Matematika berfungsi mendasari perkembangan ilmu pengetahuan dan teknologi, merupakan pengetahuan yang esensial sebagai dasar untuk bekerja seumur hidup dalam abad globalisasi (Hudojo, 2009). Dengan demikian, pelajaran matematika perlu diberikan kepada seluruh jenjang pendidikan mulai dari pendidikan anak usia dini sampai dengan perguruan tinggi. Peserta didik dibekali dengan berbagai kemampuan melalui pembelajaran matematika. Salah satu tujuan pembelajaran atau kompetensi dasar matematika di sekolah adalah agar peserta didik memiliki kemampuan memahami konsep matematika, menjelaskan keterkaitan antar-konsep dan mengaplikasikan konsep atau algoritma, secara luwes, akurat, efisien, dan tepat, dalam pemecahan masalah (Depdiknas, 2006).

Kemampuan pemahaman konsep merupakan kemampuan dasar dalam pembelajaran matematika yang harus dimiliki peserta didik. Konsep-konsep diibaratkan sebagai batu-batu pembangunan dalam berpikir (Dahar, 2011). Peserta didik memerlukan konsep sebagai pondasi atau dasar dalam berpikir untuk mempelajari maupun menyelesaikan suatu 
permasalahan. Pada dasarnya mata pelajaran matematika menekankan pada konsep (Zulkardi, 2003). Oleh karena itu, untuk mempelajari matematika peserta didik lebih dulu memahami konsep sehingga peserta didik dapat menyelesaikan soal-soal matematika. Peserta didik juga dapat mengaplikasikan pembelajaran matematika di dunia nyata serta mampu mengembangkan kemampuan lain yang menjadi tujuan dari pembelajaran matematika.

Kemampuan pemahaman konsep matematis yang belum optimal dapat disebabkan oleh beberapa faktor. Salah satu penyebab kurangnya kemampuan pemahaman konsep matematis adalah kebiasaan siswa yang belajar dengan cara menghafal (Syaiful, 2012). Peserta didik yang belajar seperti ini cenderung meniru tanpa adanya pemahaman, sehingga saat diberikan suatu permasalahan di luar materi yang diajarkan, peserta didik tidak mampu menyelesaikannya karena merasa bingung. Diperlukan peran Guru untuk membangun pemahaman konsep matematis peserta didik dengan menerapkan model pembelajaran yang tepat.

Salah satu model pembelajaran yang diharapkan mampu mempengaruhi kemampuan pemahaman konsep matematis adalah model pembelajaran M-APOS. Model pembelajaran tersebut merupakan model pembelajaran yang berpusat pada peserta didik, peserta didik mengonstruk pengetahuannya sendiri dengan bantuan guru sebagai fasilitator. Peserta didik didorong menemukan segala informasi untuk membangun konsep. Bantuan lembar kerja tugas (LKT), lembar kerja diskusi (LKD) dan bimbingan guru akan mendorong peserta didik membentuk action, process, object dan schema sehingga diharapkan konsep akan tertanam kuat pada pikiran peserta didik. Tujuan penelitian ini adalah untuk mengetahui apakah terdapat pengaruh penggunaan model pembelajaran Modification-Action, Process, Object, Schema (M-APOS) terhadap kemampuan pemahaman konsep matematis siswa di SMP Negeri 19 Bekasi pada pokok bahasan garis dan sudut.

\section{Kemampuan Pemahaman Konsep Matematis}

Pemahaman dalam pembelajaran matematika ditujukan terhadap konsep-konsep matematika sehingga dikenal dengan istilah pemahaman konsep matematis. Kemampuan dalam memahami konsep matematika diperlukan oleh peserta didik untuk berpikir menyelesaikan permasalahan matematika maupun permasalahan dalam kehidupan sehari-hari (Kesumawati, 2008). Pemahaman dalam pengertian pemahaman konsep matematis mempunyai tingkat kedalaman arti yang berbeda-beda. Salah satunya menurut Skemp dan 
Pollatsek (dalam Hendriana, Rohaeti, \& Sumarmo, 2017) terdapat dua jenis pemahaman konsep, yaitu pemahaman instrumental dan pemahaman rasional. Pemahaman instrumental menurut Skemp dan Pollatsek yaitu pemahaman atas konsep yang saling terpisah dan hanya rumus yang dihafal dalam melakukan perhitungan sederhana sedangkan pemahaman rasional yaitu digambarkan sebagai satu skema atau strukstur yang dapat digunakan pada penyelesaian masalah yang lebih luas.

Kemampuan pemahaman konsep matematis yang dimaksud dalam penelitian ini adalah kecakapan individu untuk menginterpretasikan dan mengorganisasikan informasi atau ide abstrak. Informasi atau ide abstrak yang diperoleh individu melalui pembelajaran bukan sekedar dihafal tetapi dapat diaplikasikan dalam berbagai permasalahan matematis maupun permasalahan dalam kehidupan sehari-hari secara logis dan rasional.

\section{Model Pembelajaran M-APOS}

Model pembelajaran $M$-APOS merupakan modifikasi dari teori APOS yang dikembangkan oleh Ed Dubinsky. Modifikasi yang dimaksud adalah pada fase aksi, di mana kegiatan di laboratorium komputer, diganti menjadi pemberian tugas resitasi yang diberikan sebelum pembelajaran dilaksanakan. Teori APOS memandang bahwa pengetahuan dan pemahaman matematika seseorang merupakan suatu kecenderungan seseorang untuk merespon terhadap suatu situasi matematika dan merefleksikannya pada konteks sosial, selanjutnya individu tersebut mengkonstruksi atau merekonstruksi ide-ide matematika melalui tindakan, proses dan objek matematika, yang kemudian diorganisasikan dalam suatu skema untuk dapat dimanfaatkan dalam menyelesaikan suatu masalah yang dihadapi. Menurut Dubinsky dan McDonald (2001) bahwa aksi merupakan tranformasi objek yang dilakukan oleh seseorang sebagai kegiatan eksternal. Aksi dilakukan berulang-ulang dan dilakukan refleksi terhadap aksi yang dilakukan sehingga seseorang dapat membangun konstruksi mentalnya, disebut dengan proses. Objek adalah konstruksi dari sebuah proses. Skema pada konsep matematika adalah kumpulan aksi, proses, objek dan skema lain yang mana saling berkaitan untuk konsep tertentu.

Model pembelajaran M-APOS memiliki empat karakteristik yaitu: 1) pengetahuan matematika dikonstruksi melalui tahapan konstruksi mental aksi, proses, objek dan skema, 2) menggunakan lembaran kerja terstruktur, 3) belajar dalam kelompok kecil, 4) menggunakan siklus ADL (aktivitas, diskusi kelas dan latihan) (Yerizon, 2013). Dengan demikian, M-APOS 
menggunakan siklus ADL yang terdiri dari aktivitas meliputi tahap aksi, diskusi kelas meliputi tahap proses dan objek, dan latihan meliputi tahap skema. Pembelajaran dengan model MAPOS memanfaatkan pada pemberian LKT (lembar keja tugas) yang dikerjakan siswa secara individu, tujuannya agar siswa dapat mencari informasi dan membentuk pengetahuannya sendiri dan pemberian LKD (lembar kerja diskusi) yang dikerjakan secara berkelompok pada saat pembelajaran di kelas, dengan tujuan memperdalam pemahaman siswa terhadap pengetahuan yang baru diperolehnya. Akhir pembelajaran, siswa diberikan latihan soal guna memantapkan dan menerapkan konsep-konsep yang telah dikonstruksi serta sebagai evaluasi pemahaman konsep matematis siswa. Dengan demikian, model pembelajaran M-APOS membuat peserta didik mengkonstruksi pengetahuannya sendiri dari hasil penemuan dan bukan sekedar menerima tetapi dapat menjadi bermakna.

\section{METODE PENELITIAN}

Penelitian ini merupakan penelitian eksperimen dengan variabel terikat adalah kemampuan pemahaman konsep matematis dan variabel bebas adalah model pembelajaran MAPOS. Metode penelitian yang digunakan adalah metode quasi experiment tipe the post-test only design with nonequivalent groups, seperti yang digambarkan pada Gambar 1 (Lestari \& Yudhanegara, 2017).

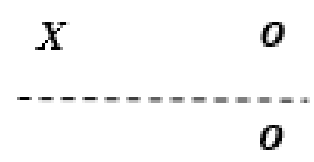

Gambar 1. Desain Penelitian

Populasi dalam penelitian ini adalah seluruh siswa kelas VII SMP Negeri 19 Bekasi yang terdaftar sebagai siswa pada semester genap tahun ajaran 2017/2018, sedangkan sampel dalam penelitian ini diambil dari dua kelas secara random sampling, yang terpilih yaitu kelas VII-1 sebagai kelas kontrol dan kelas VII-2 sebagai kelas eksperimen. Kelas eksperimen diberikan pembelajaran menggunakan model M-APOS, sedangkan kelas kontrol diberikan pembelajaran tanpa menggunakan model M-APOS. Pada penelitian ini teknik pengumpulan data dilakukan dengan menggunakan tes kemampuan pemahaman konsep matematis secara tertulis dalam bentuk uraian.

Bentuk tes yang digunakan adalah soal uraian mengenai materi garis dan sudut. Tes ini diberikan setelah perlakuan kepada kelas eksperimen dan kelas kontrol dengan tujuan 
mendapat data terakhir. Instrumen yang digunakan untuk pengambilan data penelitian terlebih dahulu diujicobakan untuk mengetahui validitas, reliabilitas, taraf kesukaran dan daya pembeda. Data dalam penelitian ini dianalisis menggunakan uji-t', karena data berasal dari populasi yang berdistribusi normal namun tidak homogen.

\section{HASIL DAN PEMBAHASAN}

Kemampuan pemahaman konsep matematis siswa dilihat dari skor tes matematika pada pokok bahasan garis dan sudut. Kelas eksperimen yang pembelajarannya menggunakan model M-APOS diikuti oleh 39 siswa, sedangkan kelas kontrol yang pembelajarannya tanpa menggunakan model M-APOS diikuti oleh 34 siswa.

Indikator pemahaman konsep matematis yang termuat dalam tes akhir digunakan sebagai alat pengukur kemampuan pemahaman konsep matematis siswa. Indikator yang muncul adalah: (1) menyatakan ulang sebuah konsep; (2) mengklasifikasikan objek tertentu sesuai dengan sifatnya; (3) memberi contoh dan bukan contoh; (4) menyajikan konsep dalam berbagai bentuk representasi matematis; (5) mengembangkan syarat perlu atau syarat cukup dari konsep; (6) menggunakan dan memanfaatkan prosedur atau operasi tertentu; dan (7) mengaplikasikan konsep atau algoritma dalam pemecahan masalah.

Skor rata-rata kemampuan pemahaman konsep matematis siswa yang menggunakan model pembelajaran M-APOS sebesar 16,897 dan skor rata-rata kemampuan pemahaman konsep matematis siswa tanpa menggunakan model pembelajaran M-APOS yaitu sebesar 14,412. Hal ini menunjukkan terdapat perbedaan kemampuan pemahaman konsep matematis siswa antara kelas eksperimen dan kelas kontrol. Berikut grafik prosentase indikator kemampuan pemahaman konsep matematis siswa. 


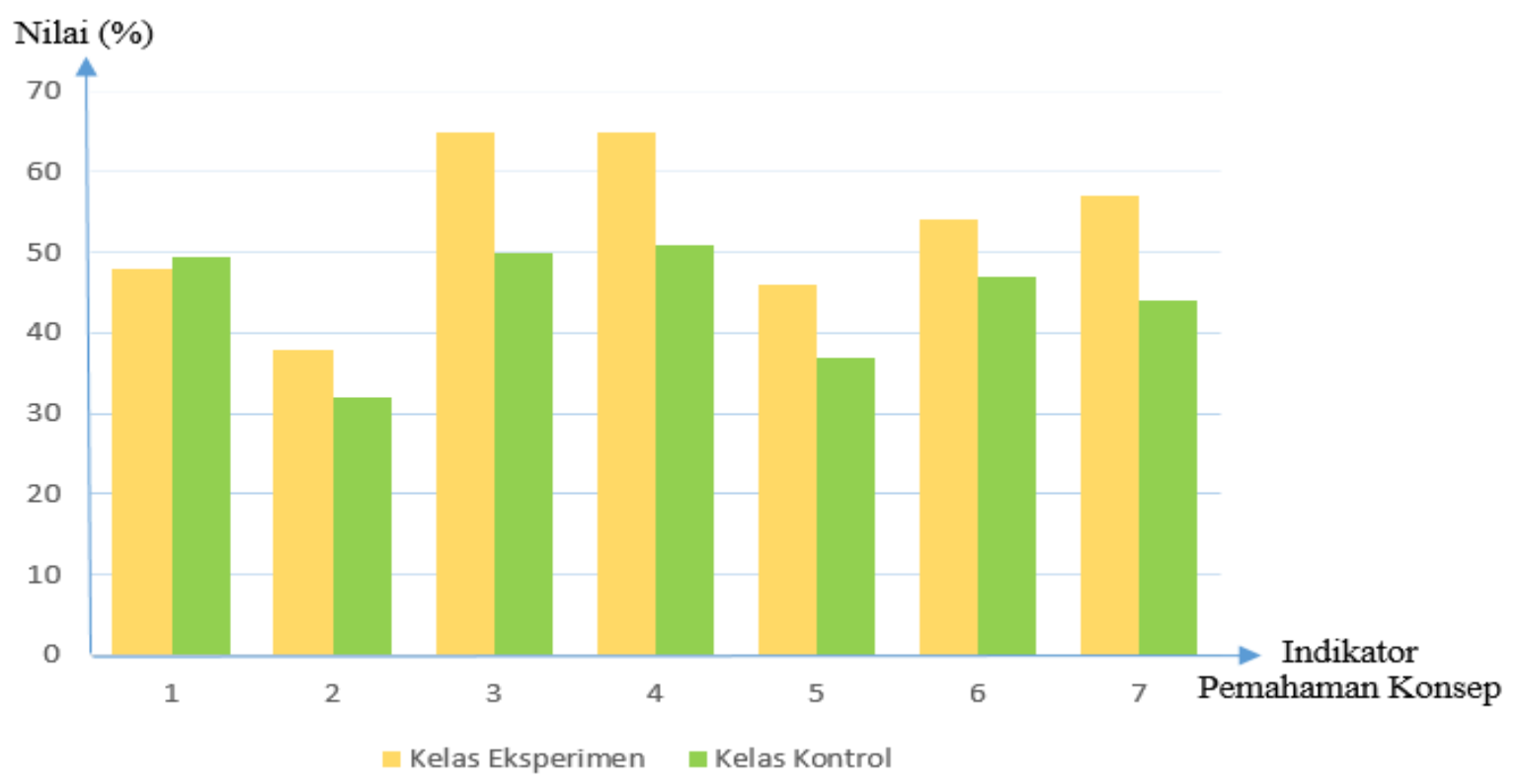

Gambar 2. Grafik Prosentase Indikator Kemampuan Pemahaman Konsep Matematis Siswa

Grafik pada Gambar 2 memperlihatkan bahwa tingkat kemampuan pemahaman konsep matematis siswa antara kelas eksperimen dengan kelas kontrol setiap indikatornya bervariasi. Kelas VII-2 sebagai kelas eksperimen dan kelas VII-1 sebagai kelas kontrol memiliki kemampuan pemahaman konsep matematis yang berbeda. Berdasarkan perhitungan uji hipotesis statistik menggunakan uji-t', diperoleh $\mathbf{t}^{\prime}$ hitung lebih dari tabel sehingga $\mathrm{H}_{0}$ ditolak. Ditolaknya $\mathrm{H}_{0}$, dapat disimpulkan bahwa terdapat pengaruh penggunaan model pembelajaran Modification-Action, Process, Object, Schema (M-APOS) terhadap kemampuan pemahaman konsep matematis siswa di SMP Negeri 19 Bekasi pada pokok bahasan garis dan sudut.

\section{KESIMPULAN}

Berdasarkan hasil penelitian terlihat adanya pengaruh penggunaan model pembelajaran M-APOS terhadap kemampuan pemahaman konsep matematis siswa. Dengan demikian, dapat disimpulkan bahwa terdapat pengaruh penggunaan model pembelajaran M-APOS terhadap kemampuan pemahaman konsep matematis siswa di SMP Negeri 19 Bekasi.

\section{REFERENSI}

Dahar. (2011). Teori-Teori Belajar dan Pembelajaran. Jakarta: Erlangga.

Depdiknas. (2006). Peraturan Menteri Pendidikan Nasional No. 22 Tahun 2006 tentang Standar Isi untuk Satuan pendidikan Dasar dan Menengah. Jakarta: Depdiknas. 
Dubinsky, E., \& McDonald, M. A. (2001). APOS: A Constructivist Theory of Learning In Undergraduate Mathematics Education Research. In The teaching and learning of mathematics at university level (pp. 275-282). Springer, Dordrecht.

Hendriana, H., Rohaeti, E. E., \& Sumarmo, U. (2017). Hard Skills Dan Soft Skills Matematik Siswa. Bandung: Refika Aditama.

Hudojo. (2009). Mengajar Belajar Matematika. Jakarta: Depdikbud, Dirjen Dikti, P2LPTK.

Kesumawati, N. (2008). Pemahaman Konsep Matematik dalam Pembelajaran Matematika. Tersedia di http:// http://eprints.uny.ac.id/6928/1/P18\%20Pendidikan\%28Nila\%20K\%29.pdf, diakses pada 10 Agustus 2017.

Lestari, K. E., \& Yudhanegara. (2017). Penelitian Pendidikan Matematika. Bandung: PT. Refika Aditama.

Mulyono, dkk. (2017). Pengaruh Model Pembelajaran Reciprocal Teaching Terhadap Kemampuan Pemahaman Konsep Matematika Siswa SMP. Jurnal Educate, 1(2).

Syaiful. (2012). Peningkatan Kemampuan Pemecahan Masalah Matematis. Melalui Pendekatan Pendidikan Matematika Realistik. Jurnal Edumatika, 2(1), 36-44.

Undang-Undang Republik Indonesia No.20 Tahun 2003 Tentang Sistem Pendidikan Nasional. Tersedia di http://www.kelembagaan.ristekdikti.go.id/wpcontent/uploads/2016/08/ U_no_20_th_2003.pdf, diakses pada 15 Juni 2017 pukul 15.35 WIB.

Yerizon. (2013). Peningkatan Kemandirian Belajar Mahasiswa Melalui Pengunaan Pendekatan Modifikasi APOS. Jurnal FMIPA Universitas Lampung, 557-563.

Zulkardi. (2003). Pendidikan Matematika Realistik Indonesia. Tersedia di http://pmri.or.id/, diakses pada 12 Januari 2018. 